Immunobiol., vol. 169, pp. 97-102 (1985)

Max-Planck-Institut für Immunbiologie, Freiburg, Federal Republic of Germany

\title{
Recombinant Human Interleukin 2 Acts as a B Cell Growth and Differentiation Promoting Factor*
}

\author{
F. EMMRICH, H. MOLL, and M. M. SIMON
}

Received July 27, 1984 - Accepted September 7,1984

\begin{abstract}
Human B cells appropriately activated by a B cell mitogen are rendered susceptible to human Interleukin 2 (IL-2) as demonstrated with recombinant human IL-2 (rec. h IL-2). They show increased proliferation and drastically enhanced immunoglobulin secretion. Susceptibility to IL-2 is accompanied with the expression of the IL-2 receptor (Tac antigen) on B cells. The data suggest that IL-2 is one of the lymphokines directly involved in the activation of B lymphocytes.
\end{abstract}

\section{Results and Discussion}

Interleukin 2 (IL-2) has been considered as a lymphokine which acts exclusively on T cells by binding to the IL-2 receptor which is exposed after appropriate activation $(1,2)$. It is known as a sialoglycoprotein of molecular weight 15,000 (3) with hormone-like activity. IL-2 is required for proliferation and expansion of $\mathrm{T}$ cells in long-term culture in vitro. In general, short-term culture supernatants of polyclonally activated lymphocytes have been used as IL-2 sources which obviously contain, beside II -2, a variety of other lymphokines difficult to separate biochemically. Even cloned $T$ cell lines may produce several lymphokines $(4,5)$. However, since recombinant IL-2 is now available a more precise functional analysis of that molecular entity should start.

Here we demonstrate that human recombinant IL-2 (rec. h IL-2, Sandoz, Wien) promotes proliferation (Table 1) and differentiation (Table 3 ) of human B cells extensively deprived of $T$ cells and prestimulated with an

* This study was supported by the Deutsche Forschungsgemeinschaft grant Em 34/1-1.

Abbreviations: $A E T=2$-aminoethyl-isothiouronium bromide hydrobromide; FCS $=$ fetal calf serum; $I g=$ Immunoglobulin; $I L-2=$ Interleukin 2; rec. $h I L-2=$ Human Interleukin 2, expressed in E. coli by recombinant DNA techniques; $S A C=$ Staphylococcus A strain Cowan I. 
appropriate B cell activator. B cell proliferation was determined by ${ }^{3} \mathrm{H}-$ thymidine incorporation whereas differentiation was determined as increased immunoglobulin secretion in culture supernatants measured by solid-phase ELISA. In order to rule out an effect of rec. h IL-2 on residual $\mathrm{T}$ cells, this population was removed carefully. This was achieved by rosetting human lymphocytes from spleen or peripheral blood by AETtreated sheep erythrocytes followed by lysis of the remaining $T$ cells with two distinct monoclonal (mAb) anti-T cell antibodies (OKT 3, Ortho; Lyt $3, \mathrm{NEN}$ ) and rabbit complement. In addition, to exclude minimum contamination by $\mathrm{T}$ cells, cultures with low cell concentrations $\left(2.5 \times 10^{4} \mathrm{~B}\right.$ cells per round-bottom microtiter well) were established for both proliferation and Ig secretion. Cytofluorometric analyses revealed no contamination of $\mathrm{T}$ cells considering a detection threshold of $1 \%$ (data not shown). More importantly, $\mathrm{T}$ cell depletion of the B cell preparation was demonstrated functionally in assays for proliferation and $\mathrm{Ig}$ secretion using the $\mathrm{T}$ cell mitogenic mAb OKT 3 (see ref. 6). It is shown that this monoclonal antibody added either directly or in the presence of rec. h IL-2 to T cell depleted $\mathrm{B}$ lymphocyte populations failed to induce proliferative responses comparable to those with rec. h IL-2 alone (Table 1). Control experiments showed that purified T4 cells are only activated under similar conditions in the presence of exogenous accessory cells (Table 2) as reported before (7). The fact that the addition of the same amount of exogenous accessory cells to the enriched B cell population did neither support an activation by

Table 1. Proliferation of human B cells promoted by rec. h IL-2 as second signal

\begin{tabular}{llrr}
\hline $\begin{array}{l}\text { Pre- } \\
\text { activation } \\
\text { (1. Signal) }\end{array}$ & $\begin{array}{l}\text { rec. h IL-2 } \\
(\mathrm{ng} / \mathrm{ml}) \\
(2 . \text { Signal }\end{array}$ & Exp. 1 & cpm \\
\hline- & - & 102 & 102 \\
SAC & - & 2908 & 870 \\
- & $+(50)$ & 870 & 1543 \\
SAC & $+(10)$ & 8280 & n.d. \\
SAC & $+(50)$ & 12800 & 6420 \\
OKT3 & - & 140 & 114 \\
OKT3 & $+(50)$ & 920 & 1384 \\
\hline
\end{tabular}

Human B cells were prepared as rosette-negative populations from spleen lymphocytes by rosetting with AET-treated sheep erythrocytes followed by complement-mediated cytolysis of residual T cells by OKT3 and Lyt3 combined with depletion of monocytes by plastic dish adherence. $2.5 \times 10^{4} \mathrm{~B}$ cells were cultured in triplicates in $200 \mu \mathrm{l} \mathrm{RPMI} 1640$ (Gibco) supplemented with $10 \%$ FCS. Heat-killed SAC particles $(0.001 \% \mathrm{v} / \mathrm{v})$ or OKT3 $(2.5 \mathrm{ng} / \mathrm{ml})$ were used as first signal and rec. h IL-2 $(10$ or $50 \mathrm{ng} / \mathrm{ml} \triangleq 100$ and 500 arbitrary units) as second signal. The functional activity of rec. $\mathrm{h} \mathrm{IL-2}$ was determined by standard titrations using the IL-2 dependent T cell line CTLL-2 (kindly provided by Dr. S. Gillis [Seattle, WA, USA]). One unit was arbitrarily defined as the amount of rec. h IL-2 $(=100 \mathrm{pg})$ which guarantees half maximal proliferation of $2 \times 10^{3} \mathrm{CTLL}$ after $24 \mathrm{~h}$. Mean cpm values are given in the Table ( $3 \mathrm{~d}$ culture, $18 \mathrm{~h}{ }^{3} \mathrm{H}$-thymidine incorporation, $1 \mu \mathrm{Ci}$ per culture). 
Table 2. Proliferation of the human T4 subpopulation induced by rec. h IL-2 as second signal

\begin{tabular}{|c|c|c|c|}
\hline $\begin{array}{l}1 \times 10^{3} \\
\text { monocytes added } \\
\text { per culture }\end{array}$ & $\begin{array}{l}\text { Pre- } \\
\text { acitivation } \\
\text { (1. Signal) }\end{array}$ & $\begin{array}{l}\text { rec. h IL-2 } \\
10 \mathrm{ng} / \mathrm{ml} \\
\text { (2. Signal) }\end{array}$ & cpm \\
\hline - & - & - & 38 \\
\hline - & - & + & 128 \\
\hline+ & OKT3 & - & 256 \\
\hline - & OKT3 & + & 973 \\
\hline+ & OKT3 & + & 8125 \\
\hline
\end{tabular}

Human T4 (helper/inducer) cells were prepared by AET-rosetting followed by a second rosetting-step with OKT4-Protein A coupled sheep erythrocytes. Monocytes were obtained as plastic adherent blood lymphocytes. OKT3 and rec. h IL-2 were used according to Table 1. 2.5 $\times 10^{4} \mathrm{~T} 4$ cells were cultured in triplicates in $200 \mu \mathrm{l}$ RPMI 1640 with $10 \%$ FCS. Mean cpm values are given ( $3 \mathrm{~d}$ culture, $15 \mathrm{~h}{ }^{3} \mathrm{H}$-thymidine incorporation, $1 \mu \mathrm{Ci}$ per culture).

OKT3 nor influence the B cell activation by Staphylococcus A strain Cowan I particles (SAC) again indicates the lack of contaminating $\mathrm{T}$ cells and suggests that $\mathrm{B}$ cell activation by SAC is accessory cell independent ( $\mathrm{F}$. EMMRICH, manuscript in preparation).

The SAC commonly used as polyclonal pre-activators for the determination of human B cell growth and B cell differentiation $(8,9)$ were prepared as described (10). As shown in Table 1, SAC by itself stimulates B cells to proliferate to a certain extent as described recently (8). The simultaneous addition of rec. h IL-2 resulted in a further substantial increase of ${ }^{3} \mathrm{H}$ -

Table 3. IgG secretion of human B cells induced by rec. h IL-2 as second signal

\begin{tabular}{lllc}
\hline $\begin{array}{l}\text { T cells added } \\
\text { per culture }\end{array}$ & $\begin{array}{l}\text { preactivation } \\
(1 . \text { Signal) }\end{array}$ & $\begin{array}{l}\text { rec. h IL-2 } \\
\text { (2. Signal) }\end{array}$ & $\begin{array}{l}\text { IgG } \\
\text { (ng/ml) }\end{array}$ \\
\hline- & - & - & 0 \\
- & SAC & - & 190 \\
- & - & $+(50)$ & 0 \\
- & SAC & $+(10)$ & 12100 \\
- & SAC & $+(50)$ & 25000 \\
- & OKT3 & - & 0 \\
- & OKT3 & $+(50)$ & 0 \\
$10^{3}$ & OKT3 & $+(50)$ & 2.5 \\
$5 \times 10^{3}$ & OKT3 & $+(50)$ & 50 \\
\hline
\end{tabular}

For B cell preparation see Table 1. T cells were prepared by AET-rosetting from peripheral blood lymphocytes. The T cell population contained $60 \% \mathrm{~T} 4$ cells as indicated by cytofluorometry. $2.5 \times 10^{4} \mathrm{~B}$ cells were cultured for 12 days in triplicates in $200 \mu \mathrm{l}$ RPMI 1640 supplemented with $10 \%$ FCS. SAC, OKT3 and rec. h IL-2 were used according to Table 1. Human IgG was determined in culture supernatants by a solidphase ELISA using dilutions of a WHO-calibrated human serum as reference. ( 0 ) indicates values below $1 \mathrm{ng} /$ as determined from the standard curve. 

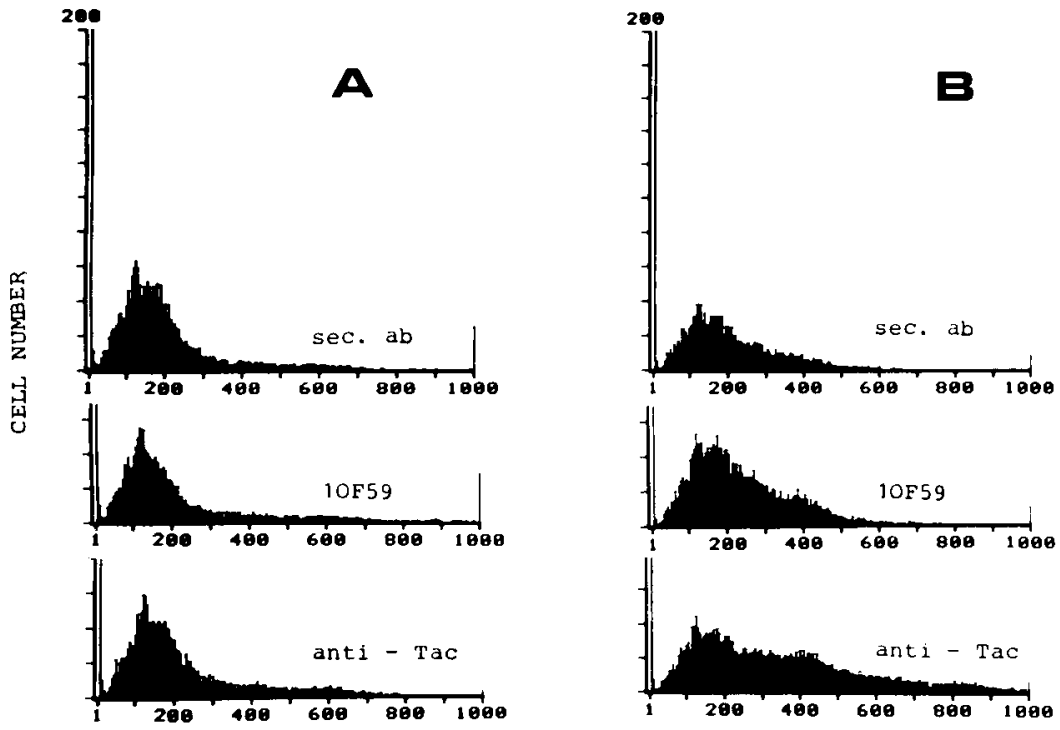

RELATIVE FLUORESCENCE INTENSITY

( log scale)

Fig. 1. The human IL-2 receptor (Tac-antigen) is expressed after appropriate preactivation of $B$ cells. For B cell preparation see Table 1. Samples of cryopreserved human B cells were cultured for two days with $0.001 \%$ SAC (B) or thawed directly before staining (A). Tac expression was analyzed cytofluorometrically (Ortho 50-H) using an FITC labelled anti-mouse-Ig F(ab') (Tago) as second antibody. For control, either the second antibody alone (sec. ab) or an irrelevant monoclonal antibody (10F59) of the same isotype as anti-Tac $(\operatorname{IgG~} 2 \mathrm{a} / \mathrm{K})$ was used. $10 \mathrm{~F} 59$ is directed to a human Ig idiotope (13). Anti-Tac and 10F59 were adjusted to same Ig concentrations $(2 \mu \mathrm{g} / \mathrm{ml})$. The threshold of positive versus negative cells was adjusted so that 6-10\% fluorescence-positive cells were found in the controls. Under these conditions, $28.4 \%$ Tac-positive cells were found in presensitized human B cells.

thymidine incorporation indicating growth factor activity of IL-2 for preactivated $\mathrm{B}$ cells. When added alone, the rec. h IL-2 by itself could induce low but significant proliferation which is presumably due to low numbers of B cells pre-activated either in vivo or by fetal calf serum components present in the cultures.

Although the rec. h IL-2 is prepared from E. coli and contains a minute contamination of bacterial lipopolysaccharide $(0.27 \mathrm{ng}$ LPS/mg IL-2 as determined in the Limulus assay by Sandoz, Wien, it should be noted that in the human system LPS does not act as a polyclonal B cell activator (11). Moreover, the quantities of LPS used for polyclonal activation of mouse B cells differ in some orders of mangitude from possible LPS contaminations in the rec. h IL-2 preparation. LPS preparations (kindly provided by Dr. C. GALANOS, Freiburg, FRG) showed no direct proliferative effect on human $B$ cells nor did they provide an additional signal after appropriate preactiva- 
tion (data not shown). Table 3 demonstrates the pronounced promoting effect of rec. h IL-2 for IgG secretion in purified B cells preactivated by SAC, whereas SAC alone, as well as rec. h IL-2 alone, failed to do so. Again, the addition of small amounts of $T$ cells to the $B$ cell culture did not support a comparable IgG secretion (Table 3).

Studies were undertaken to investigate the putative IL-2 receptor on B cells. As shown in Fig. 1, a monoclonal antibody which has been demonstrated to bind to the human IL-2 receptor on activated T cells (anti-Tac, ref. 12) also stained SAC-activated B cells. In addition, the same anti-Tac antibody could inhibit the transmission of the signal provided by rec. h IL2 (F. EMMRICH, manuscript in preparation). The combined data, therefore, argue for the expression of similar IL-2 receptors on both $\mathrm{B}$ and $\mathrm{T}$ cells activated by the appropriate mitogens.

In conclusion, the data presented show clearly that activated human B cells are susceptible for signals provided by rec. h IL-2 and suggest that this lymphokine is involved in the differentiation and proliferation of B lymphocytes. Similar results have also been obtained with the same IL-2 source using antigen or mitogen activated mouse B lymphocytes (H. Moll et al., manuscript in preparation). Thus, recombinant lymphokine probes appear to be very useful reagents to reexamine well-established views concerning lymphokine functions.

\section{Acknowledgements}

The author wish to thank the Sandoz Forschungsinstitut, Wien, for the gift of a recombinant human IL-2 probe and Dr. T. A. WALDMANN (NIH) who kindly provided the monoclonal anti-Tac antibody. Furthermore, the technical assistance of Mr. N. JosWIG and Mrs. C. RIESTERER is gratefully acknowledged. For discussing the manuscript we thank Dr. K. EICHMANN.

\section{References}

1. Morgan, D. A., F. W. Ruscetti, and R. Gallo. 1976. Selective in vitro growth of T lymphocytes from normal human bone marrows. Science 193: 1007.

2. SMith, K. A., S. Gillis, and R. C. Gallo. 1979. In: The Molecular Basis of Humane Cell Function (Ed. Kaplan, J. G.). Elsevier, N. Y., p. 223.

3. SMITH, K. A. 1981. T-cell growth factor. Immunol. Rev. 51: 337.

4. DenNer, G., S. WeISS, and J. Warner. 1981. T cells may express multiple activities: Specific allohelp, cytolysis and delayed type hypersensitivity are expressed by a clone $T$ cell line. Proc. Natl. Acad. Sci. USA 78: 4540.

5. Glasebrook, A., M. Sarmiento, M. Loken, D. Dialynas, and I. Quintans. 1981. Murine T lymphocyte clones with distinct immunological functions. Immunol. Rev. 54: 225.

6. van Wauwe, I. P., J. R. DeMey, and J. G. Goosens. 1980. OKT 3: A monoclonal antihuman $T$ lymphocyte antibody with potent mitogenic properties. J. Immunol. 124: 2708.

7. LandegreEN, U., J. ANDersson, and H. Wigzell. 1984. Mechanism of T lymphocyte activation by OKT 3 antibodies. A general model for T cell induction. Eur. J. Immunol. 14: 325 . 
8. Hirano, T., T. Teranishi, and K. OnOue. 1984. Human helper T cell factor(s). III. Characterization of B cell differentiation factor I (BCDFI). J. Immunol. 132: 229.

9. Muraguchi, A., and A. S. FaUCI. 1982. Proliferative responses of normal human B lymphocytes. Development of an assay system for human B cell growth factor (BCGF). J. Immunol. 129: 1104.

10. GODING, J. W. 1978. Use of staphylococcal protein A as an immunological reagent. J. Immunol. Meth. 20: 241.

11. Bona, C., C. Damais, C. Galanos, and L. Chedid. 1975. The mitogenic activity of lipopolysaccharides on lymphocytes in culture. II. Comparative study in five mammalian species. In: Gram-negative Bacterial Infections and Mode of Endotoxin Actions. B. UrbascheK, R. UrbascheK, and E. Neter (eds.). Springer-Verlag, Wien, New York, p 182.

12. Leonard, W. J., I. M. Deprer, T. Uchiyama, K. A. Smith, T. A. Waldmann, and W. C. GREENE. 1982. A monoclonal antibody that appears to recognize the receptor for human $\mathrm{T}$ cell growth factor; partial characterization of the receptor. Nature 300: 267.

13. ZeNKe, G. K., K. EICHMANN, and F. EMMrICH. 1984. Characterization of a major human antibody clonotype $(1 \mathrm{~A})$ by monoclonal antibodies to combining site-associated idiotopes. Eur. J. Immunol. 14: 164.

Dr. F. EMmRich, Max-Planck-Institut für Immunbiologie, Stübeweg 51, D-7800 FreiburgZähringen, FRG 